\title{
EFFECT OF NUTRITION AND PHYSICAL FACTORS ON MYCELIAL GROWTH AND SPORE PRODUCTION OF CHECKED Curvularia prasadif, A MYCOHERBICIDE AGENT FOR BARNYARD GRASS (Echinochloa crus-galli) IN RICE \\ Shabana,Y. M. ; A. H. AbouTabl and M. E. Sadek \\ Plant Pathology Department, Faculty of Agriculture, Mansoura University, El-Mansoura, Egypt \\ Yassershabana2@yahoo.com
}

\begin{abstract}
Echinochloa crus-galli is an important weed in rice paddies. The optimum cultural and physical conditions for production of Curvularia prasadii (CP01, CP02, and CP03 isolates), a biocontrol agent for the rice weed, E. crus-galli, were determined. Culture media, light regime, $\mathrm{pH}$, incubation temperature, and aeration were tested for their effect on the mycelial growth and spore production of the fungal biocontrol agent. Showed to be the best medium for the linear growth of the three isolates of the fungus was malt extract agar (MEA). Maximum yield of spores of the three isolates was obtained on potato dextrose agar (PDA). Contentious darkness was the most suitable light regime for the mycelial growth and sporulation of the CP01 and $\mathrm{CP} 02$ isolates, while contentious or diurnal light were best for CP03 growth. However, all degrees light regime were sutable for the spore production of the isolate CP03, with no significant differences among them. The $\mathrm{pH}$ levels of 6,7 , and 8 induced the highest mycelial growth of the three isolates. However, the latter two $\mathrm{pH}$ levels $(7 \& 8)$ were best for the sporulation of all three isolate. The best mycelial growth was obtained at incubation temperature of $30^{\circ} \mathrm{C}$ (for $\mathrm{CP} 01$ and CP03) and $35^{\circ} \mathrm{C}$ (for CP02). For spore production, the optimum level of temperature for isolates $\mathrm{CP} 01$ and $\mathrm{CP} 02$ was $35^{\circ} \mathrm{C}$, while it was $30^{\circ} \mathrm{C}$ for CP03. Aeration level (as negatively correlated with the number of Parafilm ${ }^{\circledR}$ layers around the culture plate edge) was also tested. There was no effect of the number of Parafilm ${ }^{\circledR}$ layers (aeration level) on the CP02 mycelial growth. However, two layers of sealing culture plates with Parafilm ${ }^{\circledR}$ provided optimum level of aeration for best mycelial growth for isolates CP02 and $\mathrm{CP} 03$ and highest spore production for all three isolates.

Keywords: Biological control, mycoherbicide, Curvularia prasadii, cultural conditions,
\end{abstract} physical factors, rice, Oryza sativa, Echinochloa crus-galli.

\section{INTRODUCTION}

Rice (Oryza sativa L.) is a vital food crop for more than half of the world population (IRRI, 2012; Luo \& Yin, 2013). In Egypt, rice comes the second major cereal crops following wheat, and the annual cultivated area is about 1.42 million feddan, produces nearly 5.89 million tons of paddy rice. The average of production is $4.15 \mathrm{t} / \mathrm{fed}$, which ranks as one of the highest average yield in the world (RRTC, 2012).

Weeds are considered the most serious factor affecting rice production because they compete for nutrients, light, and water. About 350 species of 150 genera and 60 families have been reported as rice weeds throughout the world (Hill et al., 1990; Safari, 2010). Normally the loss in rice yield due to weeds infestation ranges between $15-20 \%$. However, in severe cases the 
yield losses can be more than 50\%, depending upon the species and intensity of weeds (Mamun, 1990; BRRI, 2006).

Echinochloa crus-galli is one of the most serious weeds affecting rice in all methods of rice establishment. Biological control of weeds is an alternative approach to chemical control, which causes hazards to the environment and pose risk to human health in addition to evolution of resistant weeds. Much research on the development of new mycoherbicides has been conducted during the two past decades worldwide. Several weeds have been targeted for microbial control (Boyette \& Walker, 1985; TeBeest et al., 1992; Schroeder, 1993; Johnson et al., 1996; Imaizumi et al., 1997; Thomas et al., 1998; Montazeri \& Greaves, 2002), but little attempts has been reported for barnyard grass. Applying mycoherbicides is the most essential measure in controlling weeds with biological backgrounds, particularly in the sustainable agriculture because they target ecosystem much less than controlling factors such as herbicides. In addition, they perform quite selectively and cause minimum damages to crops (Charudattan, 2001; 2005).

As populations of aquatic monocot weeds resistant to registered herbicides appear, there is increasing interest in the use of naturally occurring pathogens of weeds as potential biological control agents (Charudattan, 1985; 1991; Morin, 1993). Hence, the aim of the present work was to know the basic knowledge about the actual weed problem in rice fields and the possibilities to integrate potential mycoherbicides into the farming system in Egypt. An attempt was done to formulate and, thereafter to test efficacy of safe and effective bioherbicides to control weeds in rice instead of using toxic chemical substances. The specific objective of the current research was to determine the optimum cultural and physical conditions for production of Curvularia prasadii, a biocontrol agent for barnyard grass, a serious rice weed.

\section{MATERIALS AND METHODS}

\section{Source of the fungal biocontrol agent:}

Surveys for diseases on rice weeds were done in Egypt in three governorates (Dakahleia, Kafr El-Sheik, and El-Gharbeia) in three consecutive growing seasons (from 2012 to 2014). Leaves of weeds showing disease symptoms were collected in polyethylene bags and kept on ice until processed in the laboratory the same day.

All fungal isolates obtained from the surveys over three years were tested for their pathogenicity against barnyard grass weed plants. By fulfilling Koch's postulates, only three isolates proved to be pathogenic on the weed causing leaf spots and blight resulting in reduction in the growth of weed seedlings in the greenhouse. Those isolates were identified as Curvularia prasadii through the Department of Survey and Identification of Fungi, Agricultural Research Center, Giza, Egypt.

Effect of Nutrition and Physical Factors on Mycelial Growth and Spore Production of the Biocontrol Agents:

Effect of culture media:

To determine the effect of nutrients on mycelia growth and sporulation of the three fungal biocontrol isolates (CP01, CP02, and CP03), four culture 
media were tested. The media used were PDA (Bio Life Italiana s. r. I. viale Monza, Milan, Italy), malt extract agar MEA) (25g malt extract $+30 \mathrm{~g}$ agar/L), carrot agar (CA) (200g fresh carrot $+20 \mathrm{~g}$ agar/L), and Czapek-Dox agar (CDA). Five-millimeter-diameter discs from a 10-day-old culture on PDA were placed in 9-cm Petri dishes containing $20 \mathrm{ml}$ of the medium and incubated at $28^{\circ} \mathrm{C}$ in darkness for 30 days. Eight replicates (plates) for mycelial growth and sporulation were used for each treatment (medium).

The diameter of the colonies was measured 2, 4, and 6 days after seeding. Spore production was quantified 30 days after inoculation. The spores were flooded with $10 \mathrm{ml}$ sterile water, diluted as 1: 10 with sterile water, stirred in a Vortex mixer and the number of spores $/ \mathrm{ml}(\mathrm{ns} / \mathrm{ml})$ in three replicates was enumerated with a haemacytometer (Shabana, 2000).

\section{Effect of $\mathrm{pH}$ :}

The $\mathrm{pH}$ of the PDA medium was adjusted to $4,5,6,7$ and 8 , using $1 \mathrm{~N}$ and/or $50 \% \mathrm{NaOH}$ and $1 \mathrm{~N} \mathrm{HCL}$ before autoclaving. The $\mathrm{pH}$ was re-adjusted after autoclaving to the same values. Five-millimeter-diameter discs from a 10day-old culture on PDA were placed on the surface of PDA medium in a 9-cmdiameter Petri dish $(20 \mathrm{ml}$ medium/plate $)$ and incubated at $28^{\circ} \mathrm{C}$ in the dark for 30 days. Eight replicates for mycelial growth and sporulation were used for each treatment.

The colony diameter was measured 2, 4, and 6 days after seeding. Spore production was quantified 30 days after inoculation. The spores were flooded with $10 \mathrm{ml}$ sterile water, diluted as 1: 10 with sterile water, stirred in a Vortex mixer and the number of spores $/ \mathrm{ml}$ in three replicates was enumerated with a haemacytometer as previously described (Shabana, 2000).

\section{Effect of temperature:}

The cultures were prepared in the same manner as described above. Inoculated Petri dishes were incubated at $15,20,25,30$, and $35^{\circ} \mathrm{C}$. Eight replicates were used for each treatment.

The colony diameter And the amount of spores were measured as described above.

\section{Effect of light regime:}

The cultures prepared as described above were incubated at $28^{\circ} \mathrm{C}$ under three light regimes: continuous darkness (CD), continuous light $(C L)$ and diurnal light (DL). Eight replicates were used for each treatment. The colony diameter And the amount of spores were measured as described above.

\section{Effect of sealing of the culture plates:}

Cultures prepared as described above were sealed with 0, 2, 4, 6, and 8 layers of Parafilm (American National Can, Greenwich, CT, USA) and incubated in darkness at $28^{\circ} \mathrm{C}$. Eight replicates were used for each treatment. The colony diameters and the quantification of spore production were measured as mentioned above. 


\section{RESULTS}

Effect of culture media:

Maximum linear growth of all three isolates (CP01, CP02, and CP03) was obtained on MEA medium. The second best medium was carrot agar medium (CA) or PDA (for CP01); CA (for CP02); and PDA (for CP03) (Table 1). However, maximum yield of spores was obtained on PDA for all three isolates (CP01, CP02, and CP03) (Table 1).

Table 1: Effect of culture media on the linear growth of mycelium and spore yield of the three isolates of the biocontrol agent Curvularia prasadii.

\begin{tabular}{|c|c|c|c|c|c|c|c|c|c|}
\hline \multirow[b]{3}{*}{ Mediumw } & \multicolumn{9}{|c|}{ Curvularia prasadii (isolate) } \\
\hline & \multicolumn{3}{|c|}{ CP01 } & \multicolumn{3}{|c|}{ CP02 } & \multicolumn{3}{|c|}{ CP03 } \\
\hline & $\begin{array}{c}\text { Mean } \\
\text { colony } \\
\text { diameter } \\
(\mathrm{cm})\end{array}$ & \begin{tabular}{|c|} 
Growth \\
rates \\
$\left(\mathrm{cm}^{-1}\right.$ \\
day $\left.^{-1}\right)$ \\
\end{tabular} & $\begin{array}{c}\text { Conidia } \\
\text { per } \mathrm{ml} \\
\times 10^{6}\end{array}$ & $\begin{array}{c}\text { Mean } \\
\text { colony } \\
\text { diameter } \\
(\mathrm{cm})\end{array}$ & $\begin{array}{c}\text { Growth } \\
\text { rates } \\
(\mathbf{c m} \\
\left.\text { day }^{-1}\right)\end{array}$ & $\begin{array}{c}\text { Conidia } \\
\text { per ml } \\
\times 10^{6}\end{array}$ & $\begin{array}{c}\text { Mean } \\
\text { colony } \\
\text { diameter } \\
(\mathrm{cm})\end{array}$ & $\begin{array}{c}\text { Growth } \\
\text { rates } \\
(\mathbf{c m} \\
\left.\text { day }^{-1}\right) \\
\end{array}$ & $\begin{array}{l}\text { Conidia } \\
\text { per ml } x \\
10^{6 x}\end{array}$ \\
\hline$(\mathrm{CA})$ & $6.30 \pm 1.39$ & $1.05 b^{y}$ & $80.60 \mathrm{~b}$ & $6.50 \pm 0.71$ & $1,08 \mathrm{~b}$ & $96.90 \mathrm{a}$ & $6.31 \pm 0.46$ & $1.05 \mathrm{c}$ & $62.32 \mathrm{~b}$ \\
\hline (CDA) & $5.50 \pm 0.96$ & $0.92 \mathrm{~b}$ & $47.92 \mathrm{c}$ & $5.00 \pm 0.46$ & $0.83 \mathrm{~d}$ & $30.10 \mathrm{c}$ & $6.36 \pm 0.81$ & $1.06 \mathrm{c}$ & $63.00 \mathrm{~b}$ \\
\hline (MEA) & $8.94 \pm 0.17$ & $1.49 \mathrm{a}$ & $61.77 \mathrm{bc}$ & 9.00 & $1.50 \mathrm{a}$ & $57.11 \mathrm{~b}$ & 9.00 & $1.50 \mathrm{a}$ & $74.48 \mathrm{~b}$ \\
\hline (PDA) & $5.59 \pm 0.47$ & $0.93 \mathrm{~b}$ & $152.84 \mathrm{a}$ & $5.55 \pm 0.34$ & $0.93 \mathrm{c}$ & $101.51 \mathrm{a}$ & $7.94 \pm 0.75$ & $1.32 \mathrm{~b}$ & $135.57 \mathrm{a}$ \\
\hline
\end{tabular}

w.CA=fresh Carrot Agar; CDA= Czapek-Dox Agar; MEA= Malt Extract Agar; PDA= Potato Dextrose Agar

${ }^{x}$ Mean number of spores $/ \mathrm{ml}$ per plate 30 days after inoculation.

y Means within a column followed by the same letter are not significantly different according to Duncan's Multiple Range test $(P=0.05)$.

\section{Effect of light regime}

Contentious darkness was the most suitable light regime for the mycelial growth and sporulation of CP01 and CP02 isolates, while contentious or diurnal light was best for CP03 linear growth (Table 2). However, all light regimes were proper for the spore production of the isolate CP03, with no significant differences among them, while continuous light produced maximum linear growth of this isolate (Table 2).

Table (2): Effect of light regime on the linear growth of mycelium and spore production of the three isolates of the biocontrol agent Curvularia prasadii.

\begin{tabular}{|c|c|c|c|c|c|c|c|c|c|}
\hline \multirow[b]{3}{*}{ Light $^{x}$} & \multicolumn{9}{|c|}{ Curvularia prasadii (isolate) } \\
\hline & \multicolumn{3}{|c|}{ CP01 } & \multicolumn{3}{|c|}{ CP02 } & \multicolumn{3}{|c|}{ CP03 } \\
\hline & \begin{tabular}{|c|} 
Mean \\
colony \\
diameter \\
$(\mathrm{cm})$
\end{tabular} & $\mathrm{r} \begin{array}{c}\text { Growth } \\
\text { rates } \\
(\mathrm{cm} \\
\left.\text { day }^{-1}\right)\end{array} \mid$ & $\begin{array}{c}\text { Conidia } \\
\text { per } \mathrm{ml} \\
\times 10^{6}\end{array}$ & $\begin{array}{c}\text { Mean } \\
\text { colony } \\
\text { diameter } \\
(\mathrm{cm})\end{array}$ & $\begin{array}{c}\text { Growth } \\
\text { rates } \\
(\mathrm{cm} \\
\left.\text { day }^{-1}\right)\end{array}$ & $\begin{array}{c}\text { Conidia } \\
\text { per } \mathrm{ml} \\
\times 10^{6}\end{array}$ & $\begin{array}{c}\text { Mean } \\
\text { colony } \\
\text { diameter } \\
(\mathrm{cm})\end{array}$ & $\begin{array}{c}\text { Growth } \\
\text { rates } \\
\text { (cm } \\
\text { day }^{-1} \text { ) }\end{array}$ & $\begin{array}{c}\text { Conidia } \\
\text { per } \mathrm{ml} \\
\times 10^{6 y}\end{array}$ \\
\hline (CD) & $3.91 \pm 0.17$ & $0.65 \mathrm{a}^{\mathrm{z}}$ & $176.10 \mathrm{a}$ & $4.33 \pm 0.23$ & $0.72 \mathrm{a}$ & $161.80 \mathrm{a}$ & $4.89 \pm 0.30$ & $0.81 \mathrm{c}$ & $92.30 \mathrm{a}$ \\
\hline$(\mathrm{DL})$ & $3.58 \pm 0.27$ & $0.60 \mathrm{~b}$ & $119.10 \mathrm{~b}$ & $3.84 \pm 0.38$ & $0.64 \mathrm{ab}$ & $52.10 \mathrm{~b}$ & $5.73 \pm 1.07$ & $0.95 \mathrm{~b}$ & $109.55 \mathrm{a}$ \\
\hline$(\mathrm{CL})$ & $3.51 \pm 0.45$ & $0.59 \mathrm{~b}$ & $63.10 \mathrm{c}$ & $3.55 \pm 0.72$ & $0.59 \mathrm{~b}$ & $57.10 \mathrm{~b}$ & $7.21 \pm 0.62$ & $21.20 \mathrm{a}$ & $100.90 \mathrm{a}$ \\
\hline
\end{tabular}




\section{Effect of $\mathrm{pH}$ :}

Maximum mycelial growth of the three isolates was obtained when the $\mathrm{pH}$ level of the culture medium was adjusted at 6,7 , and 8 . However, the latter two $\mathrm{pH}$ levels $(7 \& 8)$ have induced the maximum yield of conidia of all three isolate (Table 3 ). Thus, this fungus prefer alkali medium for growth and sporulation.

Table (3): Effect of $\mathrm{pH}$ on the linear growth of mycelium and spore production of the three isolates of the biocontrol agent Curvularia prasadii.

\begin{tabular}{|c|c|c|c|c|c|c|c|c|c|}
\hline \multirow[b]{3}{*}{$\mathrm{pH}^{\mathrm{x}}$} & \multicolumn{9}{|c|}{ Curvularia prasadii (isolate) } \\
\hline & \multicolumn{3}{|c|}{ CP01 } & \multicolumn{3}{|c|}{ CP02 } & \multicolumn{3}{|c|}{ CP03 } \\
\hline & $\begin{array}{c}\text { Mean } \\
\text { colony } \\
\text { diameter } \\
(\mathrm{cm})\end{array}$ & $\begin{array}{l}\text { Growth } \\
\text { rates } \\
\text { (cm } \\
\text { day }^{-1} \text { ) }\end{array}$ & $\begin{array}{l}\text { Conidia } \\
\text { per ml } \\
\times 10^{6}\end{array}$ & $\begin{array}{c}\text { Mean } \\
\text { colony } \\
\text { diameter } \\
(\mathrm{cm})\end{array}$ & $\begin{array}{c}\text { Growth } \\
\text { rates } \\
(\mathbf{c m} \\
\left.\text { day }^{-1}\right)\end{array}$ & 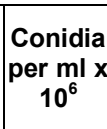 & $\begin{array}{c}\text { Mean } \\
\text { colony } \\
\text { diameter } \\
(\mathrm{cm})\end{array}$ & $\begin{array}{c}\text { Growth } \\
\text { rates } \\
(\mathbf{c m} \\
\left.\text { day }^{-1}\right)\end{array}$ & $\begin{array}{c}\text { Conidia } \\
\text { per } \mathrm{ml} \\
\times 10^{6 y}\end{array}$ \\
\hline 4 & $7.31 \pm 0.75$ & $1.22 b^{z}$ & $20.18 b$ & $8.13 \pm 0.51$ & $1.35 \mathrm{~b}$ & $31.88 \mathrm{ab}$ & $4.81 \pm 0.66$ & $0.80 \mathrm{c}$ & 36.62 bc \\
\hline 5 & $7.35 \pm 0.54$ & $1.23 \mathrm{~b}$ & $22.26 \mathrm{~b}$ & $7.68 \pm 0.38$ & $1.28 \mathrm{c}$ & $22.00 \mathrm{~b}$ & $6.06 \pm 0.79$ & $1.01 \mathrm{~b}$ & $27.79 \mathrm{c}$ \\
\hline 6 & 9.00 & $1.50 \mathrm{a}$ & $22.16 \mathrm{~b}$ & $8.95 \pm 0.11$ & $1.49 \mathrm{a}$ & $28.23 \mathrm{~b}$ & $8.75 \pm 0.27$ & $1.46 \mathrm{a}$ & $15.76 \mathrm{~d}$ \\
\hline 7 & $8.99 \pm 0.04$ & $1.50 \mathrm{a}$ & $49.29 \mathrm{a}$ & 9.00 & $1.50 \mathrm{a}$ & $44.95 a$ & 9.00 & $1.50 \mathrm{a}$ & $46.69 \mathrm{a}$ \\
\hline 8 & 9.00 & $1.50 \mathrm{a}$ & $41.02 \mathrm{a}$ & 9.00 & $1.50 \mathrm{a}$ & $44.06 \mathrm{a}$ & 9.00 & $1.50 \mathrm{a}$ & $38.91 \mathrm{ab}$ \\
\hline
\end{tabular}

${ }^{x} . \mathrm{pH}=\mathrm{pH}$ levels were tested;

${ }^{y}$ Mean number of spores $/ \mathrm{ml}$ per plate 30 days after inoculation.

z Means within a column followed by the same letter are not significantly different according to Duncan's Multiple Range test $(P=0.05)$.

\section{Effect of incubation temperature:}

The best mycelial growth was obtained at incubation temperature of $30^{\circ} \mathrm{C}$ (for $\mathrm{CP} 01$ and $\mathrm{CP} 03$ ) and $35^{\circ} \mathrm{C}$ (for $\mathrm{CP} 02$ ) (Table 4). For spore production, the optimum level of temperature for isolates CP01 and CP02 was $35^{\circ} \mathrm{C}$, while it was $30^{\circ} \mathrm{C}$ for CP03 (Table 4).

Table (4): Effect of incubation temperature on the linear growth of mycelium and spore production of the three isolates of the biocontrol agent Curvularia prasadii.

\begin{tabular}{|c|c|c|c|c|c|c|c|c|c|}
\hline \multirow[b]{3}{*}{$\begin{array}{l}\text { Temp. } \\
\left({ }^{\circ} \mathrm{C}\right)\end{array}$} & \multicolumn{9}{|c|}{ Curvularia prasadii (isolate) } \\
\hline & \multicolumn{3}{|c|}{ CP01 } & \multicolumn{3}{|c|}{ CP02 } & \multicolumn{3}{|c|}{ CP03 } \\
\hline & $\begin{array}{c}\text { Mean } \\
\text { colony } \\
\text { diameter } \\
\text { (cm) }\end{array}$ & $\begin{array}{l}\text { Growth } \\
\text { rate } \\
(\mathbf{c m} \\
\left.\text { day }^{-1}\right)\end{array}$ & $\begin{array}{c}\text { Conidia } \\
\text { per } \mathrm{ml} \\
\times 10^{6}\end{array}$ & $\begin{array}{c}\text { Mean } \\
\text { colony } \\
\text { diameter } \\
\text { (cm) }\end{array}$ & $\begin{array}{c}\text { Growth } \\
\text { rate } \\
(\mathbf{c m} \\
\left.\text { day }^{-1}\right)\end{array}$ & $\begin{array}{c}\text { Conidia } \\
\text { per } \mathrm{ml} \mathrm{x} \\
10^{6}\end{array}$ & $\begin{array}{c}\text { Mean } \\
\text { colony } \\
\text { diameter } \\
(\mathrm{cm})\end{array}$ & $\begin{array}{l}\text { Growth } \\
\text { rate } \\
(\mathbf{c m} \\
\left.\text { day }^{-1}\right)\end{array}$ & $\begin{array}{c}\text { Conidia } \\
\text { per ml } \\
\times 10^{6 y}\end{array}$ \\
\hline 15 & $2.45 \pm 0.37$ & $0.41 \mathrm{~d}^{2}$ & $69.75 \mathrm{c}$ & $2.21 \pm 0.22$ & $0.37 \mathrm{~d}$ & $54.96 \mathrm{~d}$ & $2.81 \pm 0.37$ & $0.47 \mathrm{e}$ & $55.15 \mathrm{~d}$ \\
\hline 20 & $3.24 \pm 0.57$ & $0.54 \mathrm{c}$ & $62.45 \mathrm{c}$ & $3.80 \pm 0.93$ & $0.63 \mathrm{c}$ & $141.92 \mathrm{~cd}$ & $5.31 \pm 0.84$ & $0.89 \mathrm{~d}$ & $92.45 \mathrm{~cd}$ \\
\hline 25 & $3.48 \pm 1.036$ & $0.58 \mathrm{c}$ & $185.10 \mathrm{~b}$ & $4.68 \pm 1.08$ & $0.78 \mathrm{~b}$ & $175.64 \mathrm{bc}$ & $7.71 \pm 0.79$ & $1.29 \mathrm{~b}$ & $171.60 \mathrm{~b}$ \\
\hline 30 & $5.05 \pm 0.67$ & $0.84 \mathrm{a}$ & $174.15 \mathrm{~b}$ & $5.14 \pm 0.78$ & $0.86 a b$ & $28.20 \mathrm{ab}$ & $8.57 \pm 0.26$ & $1.43 \mathrm{a}$ & $256.30 \mathrm{a}$ \\
\hline 35 & $4.26 \pm 0.87$ & $0.71 \mathrm{~b}$ & $250.40 a$ & $5.76 \pm 0.49$ & $0.96 \mathrm{a}$ & $303.36 \mathrm{a}$ & $6.54 \pm 0.59$ & $1.09 \mathrm{c}$ & $135.10 \mathrm{bc}$ \\
\hline
\end{tabular}

${ }^{x}$ incubation temperature dgree

${ }^{y}$ Mean number of spores/ml per plate 30 days after inoculation.

z Means within a column followed by the same letter are not significantly different according to Duncan's Multiple Range test $(P=0.05)$. 


\section{Effect of sealing of the culture plates}

Aeration level (as negatively correlated with the number of Parafilm ${ }^{\circledR}$ layers sealing the culture plate) was also tested. There was no significant effect of the number of Parafilm ${ }^{\circledR}$ layers (aeration level) on the mycelial growth of CP02 (Table 5). However, two layers of sealing culture plates with Parafilm ${ }^{\circledR}$ provided optimum level of aeration for maximum mycelial growth for isolates CP02 and CP03 and maximum conidial yield for all three isolates (Table 5). Also, the unwrapped cultures of isolates CP01\&CP03 induced maximum level of sporulation (Table 5).

Table (5): Effect of number of Parafilm ${ }^{\circledR}$ layers on the linear growth of mycelium and spore production of the three isolates of the biocontrol agent Curvularia prasadii.

\begin{tabular}{|c|c|c|c|c|c|c|c|c|c|}
\hline \multirow{3}{*}{$\begin{array}{l}\text { No. of } \\
\text { Parafilm } \\
\text { layers }\end{array}$} & \multicolumn{9}{|c|}{ Curvularia prasadii (isolate) } \\
\hline & \multicolumn{3}{|c|}{ CP01 } & \multicolumn{3}{|c|}{ CP02 } & \multicolumn{3}{|c|}{ CP03 } \\
\hline & $\begin{array}{c}\text { Mean } \\
\text { colony } \\
\text { diameter } \\
(\mathbf{c m})\end{array}$ & $\begin{array}{c}\text { Growth } \\
\text { rates } \\
(\mathrm{cm} \\
\left.\text { day }^{-1}\right)\end{array}$ & $\begin{array}{c}\text { Conidia } \\
\text { per ml } x \\
10^{6 y}\end{array}$ & $\begin{array}{c}\text { Mean } \\
\text { colony } \\
\text { diameter } \\
(\mathrm{cm})\end{array}$ & $\begin{array}{c}\text { Growth } \\
\text { rates } \\
\left(\mathrm{cm}^{-1}\right. \\
\left.\text { day }^{-1}\right)\end{array}$ & $\begin{array}{c}\text { Conidia } \\
\text { per } \mathrm{ml} \\
\times 10^{6}\end{array}$ & \begin{tabular}{|} 
Mean \\
colony \\
diameter \\
$(\mathrm{cm})$
\end{tabular} & $\begin{array}{c}\text { Growth } \\
\text { rates } \\
\left(\mathrm{cm}^{-1}\right. \\
\left.\text { day }^{-1}\right)\end{array}$ & $\begin{array}{c}\text { Conidia } \\
\text { per ml } x \\
10^{6}\end{array}$ \\
\hline 0 & 9.00 & $1.5 a^{z}$ & $152.79 \mathrm{a}$ & $8.37 \pm 0.23$ & $1.39 a$ & $99.95 \mathrm{bc}$ & 9.00 & $1.5 a$ & $135.99 \mathrm{a}$ \\
\hline 2 & 8.50 & $1.4 \mathrm{~b}$ & $146.25 \mathrm{a}$ & $8.43 \pm 0.17$ & $1.4 \mathrm{a}$ & $200.36 \mathrm{a}$ & 9.00 & $1.5 a$ & $125.81 \mathrm{a}$ \\
\hline 4 & 8.50 & $1.4 \mathrm{~b}$ & $74.17 \mathrm{~b}$ & $8.43 \pm 0.17$ & $1.4 a$ & $65.55 \mathrm{~b}$ & $8.27 \pm 0.43$ & $1.37 c$ & $94.27 \mathrm{~b}$ \\
\hline 6 & $8.012 \pm 0.035$ & $1.3 c$ & $99.14 \mathrm{~b}$ & 8.50 & $1.4 \mathrm{a}$ & $97.29 \mathrm{cb}$ & 8.50 & $1.4 \mathrm{~b}$ & $38.00 \mathrm{~d}$ \\
\hline 8 & $8.37 \pm 0.23$ & $1.39 \mathrm{~b}$ & $108.52 \mathrm{~b}$ & $8.43 \pm 0.17$ & $1.4 a$ & $120.34 \mathrm{~b}$ & 8.00 & $1.3 d$ & $67.06 \mathrm{c}$ \\
\hline
\end{tabular}

${ }^{y}$ Mean number of spores $/ \mathrm{ml}$ per plate 30 days after inoculation.

z Means within a column followed by the same letter are not significantly different according to Duncan's Multiple Range test $(P=0.05)$.

\section{DISCUSSION}

The specific objective of this research was to determine the optimum cultural and physical conditions for production of C. prasadii, (CP01, CP02, and $\mathrm{CP} 03$ isolates), a potential bioherbicide for barnyard grass

Alterations in nutrients in culture media used showed promotional effects on the growth of the fungal strain. Our results are in good agreement with Rabbani et al., (2011), who too reported potato dextrose broth medium as the best medium for maximum growth and sporulation of Drechslera hwaiiensis, the cause foliar blight pathogen of Marsilea minuta L. Also, our results revealed that the best medium for sporulation of the three isolates of the biocontrol agent, $C$. prasadii, was PDA medium. This finding contradict with the funding agree with that of Shabana et al. (2000) who stated that the sporulation of Alternaria eichhorniae was greatly inhibited on PDA. This disagreement may be attributed to the fact that fungi may differ in their requirements for nutrients for their growth or sporulation.

As temperature affects almost every function of the fungi (Lilly and Barnett, 1951). Our results suggest that the three isolates of $C$. prasadii have their ecological preferences. Low temperature in winter may cause a problem during biological control by influencing the activity of the biocontrol agents 
(Magan et al., 1988). Our findings support this statement since the growth of our biocontrol agent $C$. prasadii was inhibited by incubation at low temperature $\left(15\right.$ and $\left.20^{\circ} \mathrm{C}\right)$. Also, these results agree with the findings of Maity and Samaddar (1977) Zhang et al. (1996) and Shabana et al. (2000) using different fungal agents. Nagesh et al. (2007) obtained similar findings, whereas they found that the best temperature for growth of $P$. chlamydosporia was $25-35^{\circ} \mathrm{C}$. Also, our results are in line with those of Arevalo et al. (2009) who reported that the optimum temperature for growth and spore production for $P$. chlamydosporia isolates ranged between 24 and $28^{\circ} \mathrm{C}$ and those of Duponnois et al. (1995) who observed that optimum growth of $A$. oligospora occurred at $25-30^{\circ} \mathrm{C}$. Also, Nagesh et al. (2005) demonstrated that the optimum temperature for $A$. oligospora growth, sporulation, conidiospore germination and conidiospore production ranged between 25 and $35^{\circ} \mathrm{C}$. The diurnal temperature $\left(30^{\circ} \mathrm{C}\right)$ was reported as the optimum temperature for Aspergillus carbonarius growth (Mitchell et al., 2003; Bellí et al., 2004, 2005; Romero et al., 2006).

In this study, the $\mathrm{pH}$ levels of 6,7 , and 8 induced the highest mycelial growth of the three isolates. While the $\mathrm{pH}(7 \& 8)$ was best for the sporulation of all three isolate. This agree with the findings of Nagesh et al. (2007) who reported that $\mathrm{pH} 6.0$ and 7.5 were optimum for $A$. oligospora and with those of Kredics et al. (2003) who found that the optimum $\mathrm{pH}$ for $P$. chlamydosporia was 6.5-7.7. The growth rate of $A$. eichhorniae, however, increased when $\mathrm{pH}$ was raised from 4 to 7 ; the fungus grew well when the initial $\mathrm{pH}$ of culture was adjusted in the range of 5.5 to 7.5 and there is often little effect of $\mathrm{pH}$ within this range. Our results are in same trend reported by by Shabana et al. (2000) and Griffin(1988).

Aeration level (improved by not wrapping the culture plates and negatively correlated with the number of Parafilm ${ }^{\circledR}$ layers sealing the culture plate) was also tested. There was no effect of the number of Parafilm ${ }^{\circledR}$ layers (aeration level) on the CP02 mycelial growth. This contradicts the findings of Shabana et al. (2000) who reported that the mycelial growth of $A$. eichhorniae, a bioherbicides for waterhyacinth, increased by improved aeration. They found that the production of the mycelial growth of $A$. eichhorniae was greatly inhibited by increasing the Parafilm ${ }^{\circledR}$ wrappings around the culture plates. Such sealing also suppressed spore production by the fungus (Shabana, 1992). These effects may be due to a reduction of air exchange in wrapped cultures and an increase in the concentration of $\mathrm{CO}_{2}$ as suggested by Cotty (1987). In our study, two layers of sealing culture plates with Parafilm ${ }^{\circledR}$ provided optimum level of aeration for best mycelial growth for isolates CP02 and CP03 and highest spore production for all three isolates suggesting the inhibitory effect of $\mathrm{CO}_{2}$ on sporulation (Cotty, 1987).

The present results of the light regime study revealed that contentious darkness was the most suitable light regime for the mycelial growth and sporulation of the CP01 and CP02 isolates, while contentious or diurnal light were best for $\mathrm{CP} 03$ growth. However, all light regimes were proper with no significant differences for the spore production of the isolate CP03. This finding is in contradiction with that of Shabana, et al. (2000) who found that 
the mycelial growth of $A$. eichhorniae was increased by light. However, our results agree with those of Umalkar and Begum (1976) who reported that the growth rates of Alternaria brassicicola ( $A$. brassicae) (Mukadam and Deshpande, 1979) and A. tagetica (Cotty and Misaghi 1985) were decreased by exposure to light. Sporulation of many fungi is influenced by light intensity and light duration (Tan 1978). However, results of this study have shown that contentious darkness was the most suitable light regime for the sporulation of C. prasadii. In this respect, our results agree with Nagraj and Ponnappa (1970) who reported that dark periods are required for maximum production of conidiophores by $A$. brassicae,

\section{REFERENCES}

Arevalo, J., Hidalgo, D. L., Martins, I., Janaína, F., Souza., Mauro, C. J., Castro., Maria, D. R. G., Carneiro. and Myrian, S., Tigano. (2009). Cultural and morphological characterization of Pochonia chlamydosporia and Lecanicillium psalliotae isolated from Meloidogyne mayaguensis eggs in Brazil. Tropical Plant Pathology, 34(3):158-163.

Bellí, N., Pardo, E., Marín, S., Farré, G., Ramos, A.J., Sanchis, V. (2004). Occurrence of ochratoxin $A$ and potential producers on grapes from Spain. Journal of the Science of Food and Agriculture 84, 541-546.

Bellí, N., Ramos, A. J., Coronas, I., Sanchis, V., Marín, S., (2005). Aspergillus carbonarius growth and ochratoxin A production on a synthetic grape medium in relation to

Boyette, C. D. and Walker, H. L. (1985). Evaluation of Fusarium lateritium as a biological herbicide for controlling velvetleaf (Abutilon theophrasti) and prickly sida (Sida spinosa). Weed Sci. 34, 106-109.

BRRI (Bangladesh Rice Research Institute),( 2006). Weed identification and management in rice. Bangladesh Rice Research Institute, Joydebpur, Gazipur, Bangladesh

Charudattan, R. (1985). The use of genetically altered strains of pathogens for weed control. In: Biological Control in Agricultural IPM Systems, eds M. A. Hoy and D. C. Herzog. Academic Press: London, pp. 347-372.

Charudattan, R. (1991). The mycoherbicide approach with plant pathogens. In: Microbial Control of Weeds, ed. D. O. TeBeest. Chapman \& Hall, New York, pp. 24-56.

Charudattan, R. (2001). Biological control of weeds by means of plant pathogens: significance for integrated weed management in modern agro-ecology. Biocontrol, 46, 229-260.

Charudattan, R. (2005). Ecological, practical and political inputs into selection of weed targets: What makes a good biological control target? Biological Control, 35: 183-196.

Cotty, P. J. (1987). Modulation of sporulation of Alternaria tagetica by carbon dioxideMycologia 79, 508-513. 
Duponnois, R., Mateille, T. and Gueye, M. (1995). Biological characteristics and effects of two strains of Arthrobotrys oligospora from Senegal on Meloidogyne species (with reference to M. mayaguensis) parasitizing tomato plants. Biocontrol Sci Technol 5:517-525. environmental factors. Journal of Applied Microbiology 98, 839-844.

Griffin, D. H. (1981). Fungal Physiology. John Wiley and Sons, New York.

Hill J. S, Dedetta S. K, Real J. G. (1990). Echinochloa competition in rice and a comparison of studies from direct seeded and transplanted flooded rice, methods for weed management. Seameo-Biotrop. Pp 115-129.

Imaizumi, S., Nishino, T., Miyabe, K., Fujimori, T. and Yamada, M. (1997). Biological control of annual bluegrass (Poa annua L.) with a Japanese isolate of Xanthomonas campestris pv poa (JT-P482). Biol. Contr. 8, 714. in Asia. A review, limited proceeding in: IRRI, China, 2008; 87-99.

IRRI (International Rice Research Institute), Bhagirath Singh Chauhan (2012). Weed Management Indirect-seeded Rice Systems.

Johnson, D.R., Wyse, D.L. \& Jones, K.J. (1996). Controlling weeds with phytopathogenic bacteria. Weed Technol. 10, 621-624.

Kohmoto, K., R. P. Scheffer, J. O. Whiteside (1979): Host-selective toxins from Alternaria citri. Phytopathology 69, 667-671

Kredics, L.; Antal, Z.; Manczinger, L. and Szekeres, A. (2003). Influence of Environmental Parameters on Trichoderma Strains with Biocontrol Potential Food Technol. Biotechnol. 41 (1), 37- 42.

Lilly, V. G. and Barnett, H. L. (1951). Physiology of Fungi.. McGraw Hill Book Company Inc., New York, 464pp.

Luo, Y. and Yin. Z. (2013). Marker-assisted breeding of Thai fragrance rice for semi-dwarf phenotype, submergence tolerance and disease resistance to rice blast and bacterial blight. Mol. Breeding 32, 709-721.

Maity, B. R., K. R. Samaddar (1977). A toxic metabolite from Alternaria eichhorniae: production and properties. Phytopathol. Z. 88, 78-84.

Mamun, A. A. (1990). Weeds and their control: A review of weed research in Bangladesh. Agricultural and Rural Development in Bangladesh. Japan Intl. Co-operation Agency, Dhaka, Bangladesh. JSARD. 19: 45-72.

Miao, Li., Kwong, T. F. N. and Qian, P. Y. (2006). Effect of culture conditions on mycelial growth, antibacterial activity and metabolite profiles of the marine-derived fungus Arthrinium c.f. saccharicola. Appl Microbiol Biotechnol 72, 1063-1073.

Mitchell, D., Aldred, D., Magan, N. (2003). Impact of ecological factors on the growth and ochratoxin $A$ production by Aspergillus carbonarius from different regions of Europe. Aspects of Applied Biology 68, 109-116.

Montazeri, M. and Greaves, M. P. (2002). Effects of nutrition on desiccation tolerance and virulence of Colletotrichum truncatum and Alternaria alternate conidia. Biocontr. Sci. \& Technol. 12, 173-181.

Morin, L. (1993). The Prospects for Biological Control of the Noogoora Burr Complex with Naturally Occurring Fungi in Australia. PhD Thesis, University of New England, Armidale NSW. 
Nagesh, M., Hussaini, S.S., Ramanujam, B. and Rangeswaran, R. (2007). Molecolar identification, characterization, variability and infectivity of Indian isolate of the nematophagous fungus pochonia chlamydosporia. Nematol. Medit, 35, 47-56.

Nagesh, M.; Hussaini, S.S.; Chidanandaswamy, B.S. and Biswas,S. R. (2005). Isolation, in vitro characterization and predaceous activity of an indian isolate of the fungus, arthrobotris oligospra on the root-kone nematode, meloidogyne incognita. Nematol. medit., 33: 179-183.

Papavizas,G.C.(1985).Trichoderma and Gliocladium: Biology, ecology, and potential for biological control. Ann. Rev. Phytopathol. 23, 23-54.

Rabbani, N., Bajwa, R. and Javaid, A. (2011). Influence of culturing conditions on growth and sporulation of Drechslera hawaiiensis, the foliar blight pathogen of Marsilea minuta L. Afr. J. Biotechnology 10,1863-1872.

Romero, S.M., Patriarca, A., Fernández Pinto, V., Vaamonde, G, (2006). Effect of water activity and temperature on growth of ochratoxigenic strains of Aspergillus carbonarius isolated from Argentinean dried vine fruits. International Journal of Food Microbiology 115, 140-143.

RRTC (Rice Research and Training Center) (2012). Technical Recommendations for Rice Research and Training Center, Agric. Res. Center, Ministry of Agric. and Land Reclamation, Egypt.

Safari Motlagh, M. R. (2010). Identification of new fungi isolated from Echinochloa spp., as potential biological control agents in paddy fields in Iran. Scientific Research and Essays 6 (3), 567-574.

Schroeder, D., Muller-Schaerer, H. and Stinson, C.S. (1993). A European weed survey in 10 major crop systems to identify targets for biological control. Weed Res. 33, 449-458.

Shabana Y. M., Elwakil, M. A., Charudattan, R. (2000). Effect of media, light and $\mathrm{pH}$ on growth and spore production by Alternaria eichhorniae, a mycoherbicide agent for waterhyacinth. Zeitschrift für Pflanzenkrankheiten und Pflanzenschutz 107 (6), 617-626.

Shabana, Y. M. (1992): Biological Control of Waterhyacinth with Plant Pathogens. PhD Thesis. Faculty of Agriculture, Mansoura University, Egypt. 240 pp.

Thomas, H., Sauerborn, J., Muller-Stover, D., Ziegler, A., Bedi, J. S. and Kroschel, J. (1998). The potential of Fusarium oxysparum f.sp. orthoceras as a biological control agent for Orobanche cumana in sunflower. Biologic. Contr. 13, 41-48.

Tommerup, I. C., Kidby, D. K. (1980). Production of aseptic spores of vesicular-arbuscular endophytes and their viability after chemical and physical stress. Applied and Environmental Microbiology, 39, 6, 11111119 ,

Umalkar, G. V. Begum, S. (1976). Effect of light spectra on growth, sporulation, and pectic enzyme secretion in some pathogenic fungi.Biovigyanam 2, 21-25 . 
Yamaguchi, K, Ishihara, K, and Fukai, S. (2008). Wild and weed rice in rice ecosystem in Asia. A review, limited proceedings in IRRI, China, 87-99.

Zhang W. M, Moody K. Watson A. K, (1996). Responses of Echinochloa species and rice (Oryza sativa) to indigenous pathogenic fungi. Plant Dis; 80, 1053-1058.

تأثثير التغذية والعوامل الطبيعية على نمو وتجرثم الفطر كيرفيولاريـا براسـادياى -

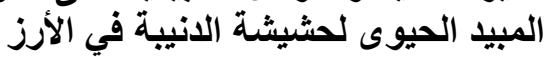

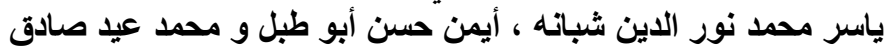

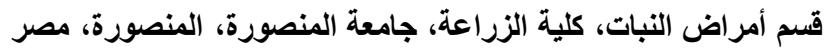

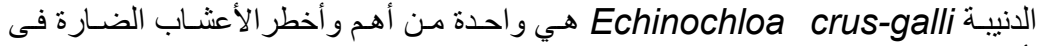

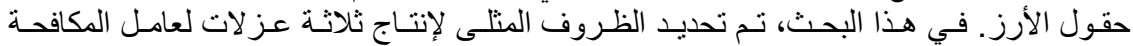

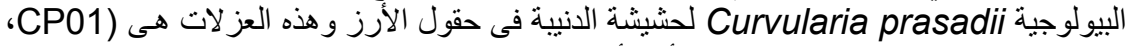

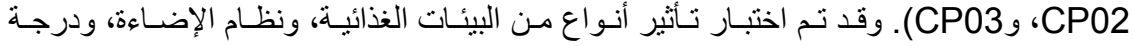

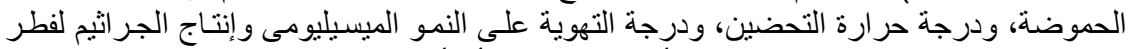

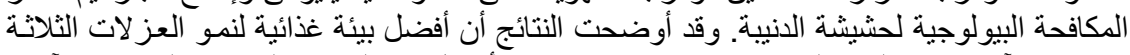

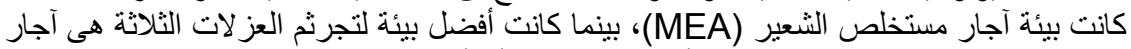

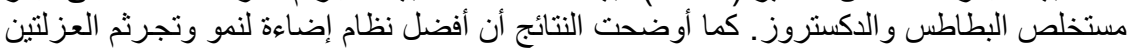

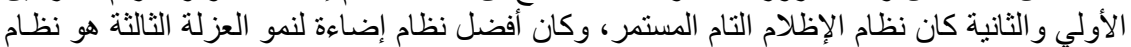

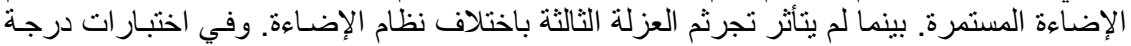

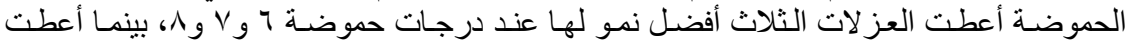

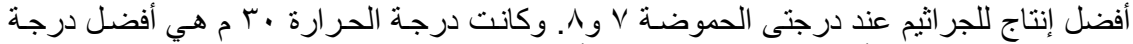

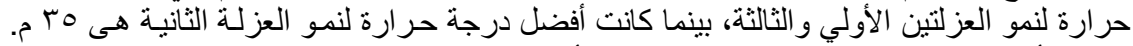

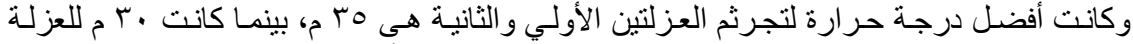

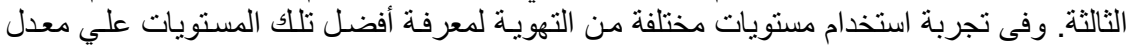

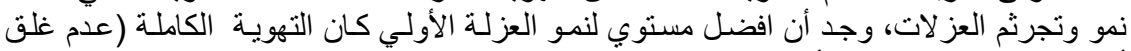

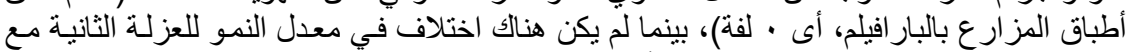

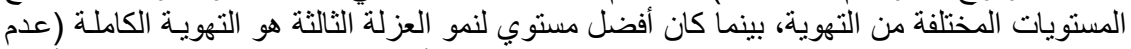

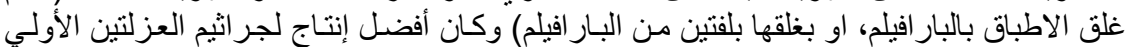

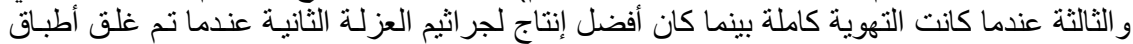
المز ارع بلفتين من البار افيلم. 